\title{
Rapid qualitative assessment to design a food basket for young Tarahumara children in Mexico
}

Joel Monárrez-Espino', Ted Greiner' and Homero Martínez²

IInternational Nutrition Research Group, Department of Women's and Children's Health, Uppsala University, Uppsala, Sweden; ${ }^{2}$ Coordinación de Investigación en Salud, Instituto Mexicano del Seguro Social, México DF, México

\section{Abstract}

Background: Infant mortality among the Tarahumaras of Mexico is high and often linked to malnutrition, such as wasting, found in $10.3 \%$ of children aged 6-23 months. This has prompted the government to offer a food-aid basket. However, this aid may often not reach the child, as the foods offered are not tailored to the Tarahumaras' cultural beliefs on young child feeding.

Objective: This study was undertaken to determine whether a different group of foods might increase the cultural acceptance of the food basket.

Design: Data were collected from 100 mothers of children aged 6-36 months from 51 communities using a combination of qualitative data collection methods, including free listing of foods from key informants, paired comparisons of food preferences, choices of foods to be added/deleted from the government basket, structured interviews about mothers' concepts related to young child feeding practices, and focus group discussions to validate findings from the previous methods.

Results: Canned sardines, cookies, lard and chocolate powder were removed from the government basket, and were replaced by beans, broad beans, green peas, milk and potatoes. Noodles, maize, sugar and salt remained from the original basket.

Conclusions: Rapid qualitative techniques proved useful in redesigning a food basket targeted towards young Tarahumara children that mothers in focus groups agreed was culturally acceptable.

Keywords: focus groups; food aid; food preference; free listing; infant feeding; pair comparisons; young child feeding

Received: 27 Oct. 2003; Revised: 7 Jan. 2004; Accepted: 22 Jan. 2004

\section{Introduction}

Throughout the world, indigenous populations have been pushed out of their habitats, as encroaching Western development has often forced them to live in marginal conditions. The Tarahumara Indians of northern Mexico are no exception. The conditions in which they live make them one of the most deprived indigenous groups in the country and affect their health status.

The climatic conditions, limitations in cultivable land and limited accessibility to fertilizers and pesticides have, along with other factors, a considerable effect on the Tarahumara agricultural productivity. The balance between these factors is frequently difficult to maintain and small changes in their components can influence the volume of crops, leading to insufficient amounts of food in the household. This eventually leaves small children at increased risk of malnutrition, as families struggle to ensure that the working members remain fit enough to carry on working. However, even when there is enough food to meet energy needs, food may not be divided within the household according to need, and micronutrient requirements may not be met.

The precarious state of Tarahumara children's health has been known for decades. The Tarahumara infant mortality rate ( 95 per 1000 livebirths) is nearly double that of the national indigenous infant mortality rate and triple that of the overall national infant mortality rate $(1,2)$. Children's anthropometry typically reveals extensive signs of chronic undernutrition. A large proportion $(57.1 \%)$ of children under 5 years is stunted (height-for- 
age $<-2 \mathrm{SD}$ ) but only a low proportion $(3.5 \%)$ is wasted (weight-for-height $<-2 \mathrm{SD}$ ). However, at more than $10 \%$ (3), wasting is more prevalent and severe in children aged 6-24 months, and is probably often associated with death. In most years, high numbers of child deaths have been reported in the local hospitals due to infectious diseases along with moderate to severe malnutrition.

Health authorities have focused on the high fatality rate associated with malnutrition among Tarahumara children. In an attempt to alleviate the problem, various governmental and non-governmental agencies have established food-aid projects, some entailing the delivering of free food baskets to Tarahumara families.

The benefits associated with supplementary feeding programmes for children, including prevention of starvation and growth failure, treatment of current malnutrition, control of morbidity and mortality, promotion of normal physiological and psychological development, and micronutrient supplementation, have been the focus of debate (4). Nevertheless, recent epidemiological evidence indicates that nutritional supplementation programmes, together with other measures such as nutrition education, during early childhood can prevent malnutrition (5).

Direct food-aid supplementation, such as that provided by the Mexican Government for Tarahumara children, can only succeed if a combination of actions is employed, including nutrition education and community participation components, and if the items included in the food basket are culturally acceptable to the recipients.

However, the foods included in the food baskets offered to the Tarahumara are rarely tailored to their cultural beliefs regarding to young child feeding practices, so they may not reach the young child and thereby may have little if any impact in increasing food intake in this group.

This study was undertaken to determine whether a different group of foods might increase the cultural acceptability of the government food basket provided for young Tarahumara children.

\section{Methods}

\section{Study area}

The Tarahumara Indians of northern Mexico live in the south-west region of the State of Chihuahua (Fig. 1), and are the most numerous indigenous

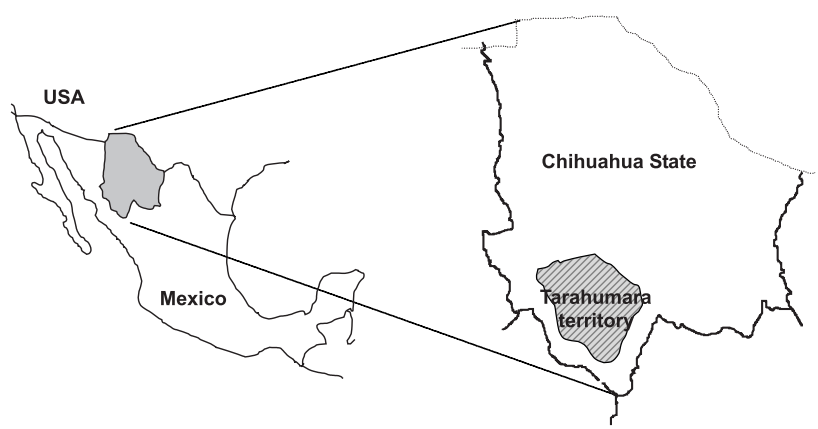

Fig. 1. Location of the Tarahumara territory in the State of Chihuahua, northern Mexico.

group of the region, with more than 80000 inhabitants (6). The land they inhabit is a high, broken plateau, cut by deep gorges and canyons. Tarahumaras live in small, loose, scattered ranch clusters. Households may be separated from each other by several kilometres. During the harsh winter, some Tarahumaras move to the deep gorges where they can escape the rigorous cold.

In most areas, dwellings primarily consist of a one-roomed log or stone house with a dirt floor and a storage hut. Furniture often consists of only a table and a few chairs. Water, electricity and sewage disposal are non-existent. Families often make their living from small-scale farming, growing mainly maize and beans in small pockets of suitable soil. Many families also raise chickens, and may try to keep goats and cattle.

Food is largely based on vegetable products, of which maize tortillas and beans are the staples. Although in the past their diet included many wild plants and animals, this pattern of food consumption has been disappearing (7) as constant and intensive human pressure has driven wild game from the region.

\section{Study design}

A combination of rapid qualitative techniques (811) was used to identify the most important food items eaten by young Tarahumara children. Focus group discussions (12) were conducted with mothers of children aged 6-36 months to gain insights from the findings, to validate the results and finally to select the items to be included in the proposed food basket (Fig. 2).

A stratified quota sampling method was used to include mothers from three different strata based on the level of marginalization of the respondents (i.e. living at the periphery of Mexican society). Char- 


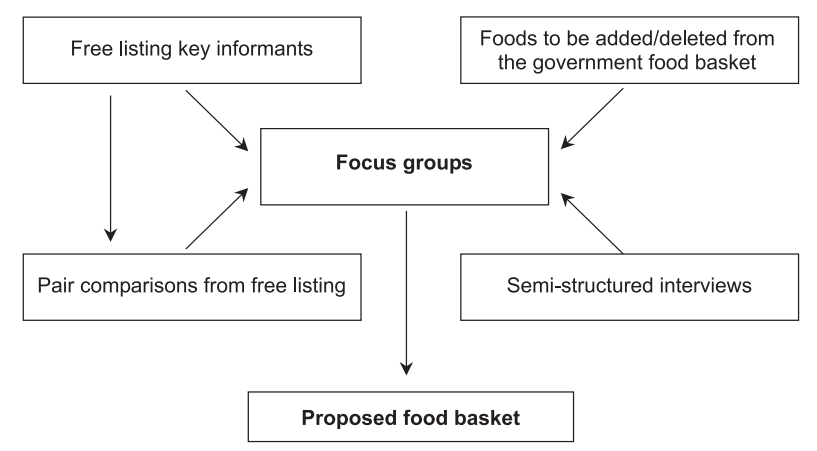

Fig. 2. Overall description of the study design used to identify food items to be included in the food-aid basket targeted to young Tarahumara children.

acteristics considered for the sampling scheme were closely related to the isolation of the population, in terms of not only the number of households in the community, but also its accessibility and the ratio of Tarahumaras to mestizos, factors likely to relate to food preferences. The level of marginalization was conventionally defined according to the overall score obtained as follows: high, 3-4 points; middle, 5-7 points; and low marginality, 8-9 points (Table 1). Interviews were conducted with the same number of mothers from each of the three pre-established strata.

\section{Data collection and analyses}

The information was gathered through the adaptation of a series of qualitative techniques that included the following.

Free listing. Nine mothers, three from each stratum, were selected as key informants. These were mostly female indigenous health-care workers and health promoters of different ages (range 23-54

Table I. Score assigned to each respondent based on selected characteristics to assign them to one of three levels of marginalization ${ }^{a}$

\begin{tabular}{llll}
\hline Characteristics & I point & 2 points & 3 points \\
\hline Number of households $^{\mathrm{b}}$ & $<10$ & $10-50$ & $>50$ \\
Accessibility $^{\mathrm{c}}$ & Very difficult & Difficult & Not difficult \\
Type of population $^{\mathrm{d}}$ & Exclusive & Predominant & Mixed \\
\hline
\end{tabular}

${ }^{a}$ High: 3-4 points; middle: 5-7 points; and low marginality: 8-9 points.

${ }^{b}$ Obtained through the National Census and corroborated locally.

c Evaluated considering time and distance from the community to the nearest health-care centre, as well as the means of transport to get there.

${ }^{d}$ Defined according the proportion of mestizo households in the community: $<10 \%$ exclusively Tarahumara; 10-30\% predominantly Tarahumara; $>30 \%$ mixed. years old). Each was asked to list the 10 foods that they considered the most appropriate for young children (Which foods or drinks do your children between 6 months and 3 years eat or drink?). The 12 foods mentioned by at least one-third of the mothers were selected for the pair comparison procedure.

Pair comparisons. Two balanced groups of six foods identified from the free listing from key informants were shown to 60 mothers with young children. Actual foods were placed in identical dishes and in similar amounts and were shown to the respondents. Twenty women from each stratum were asked to make a choice between all possible combinations $(n=15)$ in each food group, according to what they considered appropriate to feed their young children (Which one do you prefer to feed your children between 6 months and 3 years, this or this?). Foods were ranked according to how many mothers preferred them.

Listing of foods to be added or deleted. Thirty mothers, 10 from each stratum, were shown the foods included in the government food basket, in identical dishes and similar amounts, which included chocolate powder, cookies, lard, maize flour, wheat noodles, salt, canned sardines and sugar. Mothers were asked to add or delete up to five foods from this basket, according to what they considered appropriate for small children (To feed your children between 6 months and 3 years, if you could add foods to the basket: which foods would you add? And, if you had to delete foods from the basket: which ones would you prefer to delete?). Selected foods were ordered depending on how many times they were selected.

Semi-structured interviews. Twenty mothers from each sampling stratum were interviewed using a semi-structured format covering the following topics: concepts and practices on complementary feeding and breast-feeding, knowledge about appropriate complementary foods to feed young children, consistency of foods to feed young children, utensils used to feed young children, beliefs about complementary feeding and breast-feeding simultaneously, beliefs about feeding children during illness, opinions on the food basket, and attitudes towards participation in the delivery of the food basket. Results were categorized and summarized by strata.

Focus groups. Two focus group sessions, each involving five to eight mothers of different ages from the same sampling stratum (six focus groups in 
total), were conducted to validate the findings of the previous procedures. All sessions were conducted in health-care centre and school classrooms with the help of a trained simultaneous translator. Sessions lasted for 50-60 minutes. The sessions were videotaped and later translated for analysis. The group discussions gravitated towards the results from the previous phases. Each food was discussed in terms of its adequacy for young children, its nutritional value, cultural acceptability, cost, local availability, accessibility and consumption by other family members.

Statistical tests were not used to explore differences in the proportions across strata for the pair comparisons and the addition/deletion results, because it was considered inappropriate to use such tests in this relatively small non-probabilistic sample. Rather, an attempt was made to distinguish between the most and least selected foods, focusing on the three most preferred foods, to explore the need for distinct food baskets.

Data were collected over an 8 week period in the municipality of Guachochi, where one-third of the entire Tarahumara population resides (6). The study was carried out only with Tarahumara mothers of children aged 6-36 months. A trained simultaneous translator was used with mothers who were monolingual (i.e. did not speak Spanish). The study comprised 100 women selected from over 300 households visited in 51 different communities.

The study was approved by the Ethics Committee at the Mexican Institute of Public Health and by the local health authority. All respondents gave informed consent to be interviewed.

\section{Results}

The key informants mentioned a total of 31 foods thought to be the most appropriate for children aged 6-36 months. Quelite, an edible green wild plant (Amaranthus palmeri), and beans were mentioned by all nine informants; pinole, a traditional toasted maize powder prepared as gruel, and noodles were mentioned by seven; potatoes by six; green peas and chicken broth by five; eggs, tortilla (a round, thin cake of unleavened cornmeal) and coffee by four; and broad beans and sardines by three. Two out of the nine key informants mentioned another six foods, including squash, tea and chocolate powder, and another 13 foods were mentioned by only one key informant, including rice, apples and bananas.
Table 2. Proportion of respondents showing preference for each food when matched with each other food within each group in pair comparisons by level of marginalization $^{\mathrm{a}}$

\begin{tabular}{|c|c|c|c|c|}
\hline \multirow[t]{2}{*}{ Group } & \multicolumn{4}{|c|}{$\begin{array}{l}\% \text { Preferred by level of marginalization of the } \\
\text { respondents }\end{array}$} \\
\hline & High & Middle & Low & Total \\
\hline \multicolumn{5}{|l|}{ A } \\
\hline Potatoes & 76 & 75 & 72 & 74 \\
\hline Broad beans & 58 & 76 & 88 & 74 \\
\hline Noodles & 60 & 60 & 54 & 58 \\
\hline Chicken broth & 56 & 51 & 54 & 53 \\
\hline Quelite $^{\mathrm{b}}$ & 26 & 16 & 24 & 22 \\
\hline Coffee & 26 & 20 & 4 & 17 \\
\hline \multicolumn{5}{|l|}{ B } \\
\hline Eggs & 75 & 82 & 87 & 80 \\
\hline Tortilla ${ }^{c}$ & 62 & 67 & 62 & 64 \\
\hline Green peas & 58 & 45 & 58 & 53 \\
\hline Beans & 42 & 36 & 44 & 40 \\
\hline Pinole $^{d}$ & 42 & 22 & 40 & 34 \\
\hline Sardines & 24 & 47 & 9 & 27 \\
\hline
\end{tabular}

For the paired comparisons, the average age of the respondent mothers and the proportion capable of speaking Spanish in the high, middle and low marginality strata were 26.6 years, $15 \% ; 26.7$ years, $55 \%$; and 30.1 years, $95 \%$; respectively. As shown in Table 2, no major differences in the selection of foods by strata were identified: potatoes, broad beans and wheat noodles were the most preferred foods in food group A, and eggs, tortilla and green peas in group B across the three strata. The traditional foods quelite and pinole received low rankings among respondents' preferences.

Regarding listing of foods to be added or deleted from the government food basket, as shown in Table 3 , the three foods most often added were beans, green peas and potatoes, almost irrespective of the marginalization level of the respondents. Although not selected by all mothers in the three marginalization strata, wheat flour, milk, eggs, broad beans and oats were also mentioned. Canned sardines, cookies, lard and chocolate powder were the foods most often deleted, while wheat noodles, maize flour, sugar and salt were the least deleted.

The semi-structured interviews revealed no uniform criteria about the age when complementary 
Table 3. Proportion of food items selected to be added ${ }^{\mathrm{a}}$ and deleted ${ }^{\mathrm{b}}$ from the government food basket ${ }^{c}$ to feed children between 6 months and 3 years by level of marginalization $^{\text {d }}$

\begin{tabular}{|c|c|c|c|c|}
\hline \multirow[t]{2}{*}{ Foods } & \multicolumn{4}{|c|}{$\%$ Selected by level of marginalization of the respondents } \\
\hline & High & Middle & Low & Total \\
\hline \multicolumn{5}{|l|}{ Added } \\
\hline Beans & 50 & 73 & 80 & 67 \\
\hline Green peas & 40 & 90 & 45 & 58 \\
\hline Potatoes & 60 & 60 & 36 & 52 \\
\hline Wheat flour & 30 & 0 & 55 & 28 \\
\hline Milk & 50 & 30 & 0 & 27 \\
\hline Eggs & 0 & 40 & 36 & 25 \\
\hline Broad beans & 30 & 0 & 36 & 22 \\
\hline Oats & 30 & 0 & 36 & 22 \\
\hline \multicolumn{5}{|l|}{ Deleted } \\
\hline Sardines & 100 & 100 & 100 & 100 \\
\hline Cookies & 80 & 80 & 100 & 87 \\
\hline Lard & 70 & 70 & 90 & 77 \\
\hline Chocolate & 60 & 60 & 60 & 60 \\
\hline Salt & 50 & 70 & 50 & 57 \\
\hline Sugar & 50 & 60 & 50 & 53 \\
\hline Maize & 40 & 40 & 70 & 50 \\
\hline Noodles & 20 & 10 & 20 & 17 \\
\hline
\end{tabular}

a "If you could add foods to the basket, which foods would you add?".

b "If you had to delete foods from the basket, which ones would you prefer to delete?".

c Chocolate powder, cookies, lard, maize, noodles, salt, sardines and sugar.

${ }^{d}$ Based on the number of households in the community, its accessibility and the ratio of Tarahumaras to mestizos.

feeding should be initiated. Mothers for the middle and highly marginalized strata mentioned very few appropriate foods for complementary feeding and knew very few preparation methods. Harmful beliefs regarding withholding food from young children during illness were seen among highly marginalized respondents. Harmful beliefs were also associated with simultaneous complementary feeding and breast-feeding by several mothers from the middle and highly marginalized strata. Otherwise, no differences in the responses across the marginalization strata were identified for other topics. Breast-feeding up to 2 years was common, mothers used the same utensils to feed their children, and a liquid or semi-liquid consistency of the food was considered appropriate to feed young children in all strata (Table 4).

The information extracted from the six focus group discussions is summarized in Table 5. Broad beans, green peas, potatoes and noodles were acceptable for children. Mothers liked the ease of preparation and consistency of these foods, and the fact that vegetables are easy to grow. Beans and maize were also widely used, as they are part of the staple Tarahumara diet. Sugar was regarded as a multipurpose ingredient, often mentioned in liquid preparations. Salt was considered a necessary ingredient to prepare food for young children. Many mothers said, "Children would not eat if food had no salt". There was uncertainty about the appropriateness of lard as a food for young children. Cookies were seen to be related to tooth damage, and chocolate powder, oats and squash were not popular foods. Sardines and coffee were well accepted by adults, but not by children. Because wild quelites are readily found nearby, mothers preferred other foods. Several mothers said that they would like to receive eggs, but were aware that they are very difficult to transport. It was also found that some traditional foods such as pinole, often targeted for interventions by non-governmental organizations and health system-based groups, were not well accepted for inclusion in food-aid baskets, as mothers liked to prepare these foods for their families themselves.

Table 6 summarizes the nutritional value of the foods proposed for the basket. Beans and broad beans supply protein and iron. Green peas contain considerable amounts of vitamin A and vitamin C. Maize flour, wheat noodles and sugar are major sources of carbohydrates, and skimmed milk powder is an important source of protein, calcium and vitamin A.

\section{Discussion}

Although supplying food aid is neither the only nor the most important way to combat malnutrition, direct food aid, i.e. food distributed to be consumed in addition to food purchased or produced by the household, has a number of advantages over other types of assistance to improve the nutrition of a vulnerable population (13).

Food aid can make an important contribution, but it cannot alone solve the multifactorial problem of malnutrition, although it can have a large effect in the case of wasted children. Food aid needs to be combined with other efforts such as better agriculture, health care and education to be most effective in defeating malnutrition. However, it is still common for some governments to make a simplistic assumption that distributing food to affected groups can solve nutrition problems, including stunted growth. 


\begin{tabular}{|c|c|c|c|}
\hline \multirow[t]{2}{*}{ Topic covered } & \multicolumn{3}{|c|}{ Level of marginalization of the respondents } \\
\hline & High & Middle & Low \\
\hline $\begin{array}{l}\text { Concepts and practices on } \\
\text { complementary feeding }\end{array}$ & $\begin{array}{l}\text { Poor consensus about when to start } \\
\text { complementary feeding }\end{array}$ & $\begin{array}{l}\text { Consensus to start complementary feeding } \\
\text { before I year of age }\end{array}$ & $\begin{array}{l}\text { Consensus to start complementary feeding } \\
\text { before } 6 \text { months of age }\end{array}$ \\
\hline Breast-feeding practices & \multicolumn{3}{|c|}{ Most mothers breast-feed at least I year, but common up to 2 years } \\
\hline $\begin{array}{l}\text { Knowledge about complemen- } \\
\text { tary foods }{ }^{\mathrm{a}}\end{array}$ & Poor knowledge, know very few app & complementary foods & Some knowledge, know various foods \\
\hline $\begin{array}{l}\text { Consistency of foods to feed } \\
\text { young children }\end{array}$ & \multicolumn{3}{|c|}{ Liquid or semi-liquid consistency of food thought to be adequate to feed children between 6 months and 3 years } \\
\hline $\begin{array}{l}\text { Utensils used to feed young } \\
\text { children }\end{array}$ & \multicolumn{3}{|c|}{ Soup dish, glass or cup with a spoon to give meals to young children; nobody uses nursing bottles } \\
\hline $\begin{array}{l}\text { Simultaneous complementary } \\
\text { feeding and breast-feeding }\end{array}$ & Some harmful beliefs, several mother & ted that children "may get sick" & Mothers believe it is adequate for children \\
\hline $\begin{array}{l}\text { Beliefs about feeding children } \\
\text { during illness }\end{array}$ & \multicolumn{2}{|c|}{ Few harmful beliefs, "child may get worse" } & t is safe for children's health \\
\hline $\begin{array}{l}\text { Opinion towards the food } \\
\text { basket }\end{array}$ & \multicolumn{3}{|c|}{ Positive in general, but most respondents were worried about the frequency of the delivery of the food basket } \\
\hline $\begin{array}{l}\text { Participation in delivery of the } \\
\text { basket }\end{array}$ & \multicolumn{3}{|c|}{ Co-operative attitude, most mothers are willing to walk for up to $2 \mathrm{~h}$ every week to collect the food basket } \\
\hline
\end{tabular}

${ }^{\text {a }}$ Mothers were asked to list foods considered adequate for complementary feeding and to describe preparation modes.

Most nutrition interventions, including those related to behavioural change, require a level of infrastructure and human resources impossible to mobilize in a setting such as the Tarahumara where the affected families live mainly in very isolated and scattered villages, each composed of a few dozen relatively uneducated people. Thus, the food basket may be considered to be at least one useful effort to assist these people, and this study focuses on one simple and feasible way in which it may be improved, namely, by increasing the likelihood that the food is eaten by children that it targets.

Anthropological techniques have been used successfully in the past to obtain ethnographic information relevant to the development of culturally tailored solutions to health and nutritional problems in developing countries (14-17).

Rapid qualitative techniques were used in this study to identify foods eaten by young Tarahumara children, to increase the cultural acceptability of the basket provided by the government. This mixture of relatively simple methods was used because collecting valid and reliable data through other means (e.g. in-depth interviews) in this poorly educated and frequently illiterate population is a very difficult and demanding task. In addition, the results from the different techniques could be triangulated to corroborate the choices of the foods proposed for inclusion in the basket.

An inexpensive convenience quota sampling method, divided into three strata based on level of marginalization, was used to look for possible gross differences across the strata. The results, based on the pair comparisons and the additiondeletion data collection techniques, point to a relatively homogeneous judgement in the children's feeding patterns across the marginalization strata, suggesting that the use of a single food basket for all children may be acceptable to all.

The analyses identified nine culturally acceptable foods that mothers considered appropriate for young children and that could be included in the proposed food basket: beans, broad beans, green peas, potatoes, skimmed milk powder, wheat noodles, maize flour, sugar and iodized salt. Only the final four in this list were already in the government food basket. The cost of the suggested food basket was calculated and found not to be significantly 
Table 5. Results from the focus groups with Tarahumara women with young children

Foods retained from the government basket in the Maize flour: A staple food in the Tarahumara diet. Well accepted in different preparations by young children. Maize is proposed basket

easy to grow

Noodles: Preferred for children but eaten by all family members. Mothers like their easy preparation, consistency and low price

Salt: Considered a necessary ingredient in food preparation for young children ("children don't eat without it")

Sugar: A multipurpose ingredient very often mentioned in liquid preparations for young children. Considered very expensive

Foods not retained from the government basket in Cookies: Regarded as candy, hence associated with tooth damage

the proposed basket

Chocolate powder: Not well known, so it is little used. It is difficult to obtain and expensive

Lard: Related to preparation of adults' foods, viewed with reticence for small children as they may "get sick"

Canned sardines: Well accepted by adults, but not children. "With sardines children may get diarrhoea"

Culturally accepted foods not included in the proposed basket

Culturally accepted foods to be included in the proposed basket

Other foods not included in the proposed basket
Eggs: Considered a very nutritional food for small children, but most mothers stated that they are difficult to transport

Chicken broth: Although prepared when a chicken or hen is killed, it is well accepted and consumed by all family members

Pinole: Mothers feel they show their care for their family by preparing this traditional gruel. After 2 days it becomes rancid

Squash: Although not a favourite food, it is accepted by small children, but available only in season

Beans: Beans are the base of the Tarahumara diet in different preparations. Well accepted by young children and easy to grow

Broad beans: Mothers like their consistency and ease of preparation. Very well accepted by children and easy to grow Green peas: Easy to grow and to prepare, and have a soft consistency. Very well accepted by young children

Milk: Associated with children's growth, and therefore widely used for children of all ages, but especially for young children

Potatoes: Very good for children, but they are consumed by all the family. Mothers like their soft consistency and ease of preparation

Quelite: Mothers do not want to receive this edible green spinach-like wild plant, because it is readily found nearby, and because young children can choke on it or get diarrhoea

Coffee: Although very well accepted by adults, mothers stated that it is not acceptable for young children

Oats: Require special preparation for children, and even so, young children can choke on them different from the cost of the original government food basket (data not presented).

The proposed food basket included staple foods, energy-rich foods, food with high protein con- tent, and food that contained vitamins and minerals. Most of these foods are produced in nearby areas of Mexico, and all the vegetables are grown locally.

Table 6. Nutritional value of the food items included in the proposed food-aid basket

\begin{tabular}{|c|c|c|c|c|c|c|c|c|c|}
\hline \multirow[t]{3}{*}{ Proposed food item } & \multicolumn{9}{|c|}{ Per $100 \mathrm{~g}$ edible portion } \\
\hline & \multirow[t]{2}{*}{ Energy (kcal) } & \multicolumn{3}{|c|}{ Macronutrients } & \multicolumn{5}{|c|}{ Micronutrients } \\
\hline & & Carbohydrate (g) & Protein (g) & Fat (g) & Vitamin A $(\mu \mathrm{g})$ & $\mathrm{Ca}(\mathrm{mg})$ & $\mathrm{Fe}(\mathrm{mg})$ & Zn (mg) & Vitamin C (mg) \\
\hline Beans $^{\mathrm{a}}$ & 353 & 61.4 & 22.7 & 1.8 & 0 & 200 & 5.7 & 2.5 & 0 \\
\hline Broad beans $^{b}$ & 363 & 63.1 & 22.6 & 2.2 & 5.0 & 49 & 7.3 & 3.1 & 0 \\
\hline Green peas ${ }^{c}$ & $|4|$ & 25.4 & 9.0 & 0.4 & 57.0 & 37 & 2.8 & 1.2 & 60 \\
\hline Maize flour ${ }^{d}$ & 386 & 79.3 & 7.1 & 4.5 & 1.0 & 140 & 3.9 & 2.5 & 0 \\
\hline Wheat noodles ${ }^{e}$ & 388 & 86.7 & 9.4 & 0.4 & 0 & 26 & 2.1 & 0 & 0 \\
\hline Potatoes $^{f}$ & 93 & 21.3 & 1.7 & 0.1 & 0 & 11 & 2.1 & 0.3 & 17 \\
\hline Sugarg & 372 & 91.5 & 0.4 & 0.5 & 0 & 51 & 4.2 & 0 & 0 \\
\hline Skimmed milk powder & 360 & 52.0 & 36.1 & 0.8 & 8.0 & 1257 & 0.3 & 4.1 & 7 \\
\hline
\end{tabular}

a Phaseolus vulgaris, ${ }^{\mathrm{b}}$ Vicia faba, ${ }^{\mathrm{c}}$ Pisum sativum, ${ }^{\mathrm{d}}$ Zea mays, ${ }^{\mathrm{e}}$ Triticum aestivum, ${ }^{\mathrm{f}}$ Solanum tuberosum, ${ }^{\mathrm{g}}$ Saccharum officinarum.

Source: Latin American Food Composition Tables. FAO/LATINFOODS; 2002. 
However, some of the suggested foods are appreciated by other family members as well, so some intrafamily dilution may occur, particularly at times of food scarcity, which are known to exacerbate existing disparities in intrahousehold food distribution $(18,19)$. Food trading or selling also needs to be minimized, especially among the poorest people (20). Nutrition education in combination with food aid can also strengthen the impact of the intervention $(21,22)$.

Changes in attitude, knowledge and practices are essential for achieving desirable, long-term, lasting results. Inappropriate feeding practices should be discouraged and attention must be paid to hygiene, storage, preparation and safety. Similarly, a strong focus on complementary feeding and continued attention to the protection, support and promotion of breast-feeding remain key components for tackling nutrition problems.

The suggested food basket should be pilot tested for its cultural acceptability in a representative sample of households, for taste, palatability, ease of preparation, shelf-life and specific acceptability by the target children (23).

Active community participation to achieve a long-term sustainable food basket should be promoted (24), as various community-based programmes have had a substantial effect in reducing child malnutrition rates (25).

In conclusion, food aid should take into consideration the cultural acceptability of the foods offered. This rapid qualitative approach proved to be useful in redesigning a culturally acceptable food basket targeted at young children.

\section{Acknowledgements}

The study was sponsored by ITESM Campus Chihuahua and Fondo Social del Empresariado Chihuahuense. We also appreciate the assistance of Manfred Braig in the collection of the field data.

\section{References}

1. Fernández P. La mortalidad infantil indígena en 1990: una estimación a través de municipios predominantemente indígenas. México, DF: Secretaría de Salud; 1992.

2. Gómez de León J, Partida V. Niveles de mortalidad infantil y fecundidad en México por entidad federativa. México, DF: Secretaría de Salud; 1992.

3. Monárrez-Espino J, Martínez H. Prevalence of malnutrition in Tarahumara children under 5 years in the municipality of Guachochi, Chihuahua. Salud Publica Mex 2000; 42: 8-16.

4. Beaton G. Which age groups should be targeted for supplementary feeding? In: United Nations Administrative Committee on Coordination/Sub-Committee on Nutrition (UN ACC/SCN). Nutritional issues in food aid ACC/SCN Symposium report. Nutrition Policy Discussion Paper No. 12. Geneva: UN ACC/SCN; 1993. p. 37-54.

5. Shrimpton R, Victora CG, de Onis M, Lima RC, Blossner M, Clugston G. Worldwide timing of growth faltering: implications for nutritional interventions. Pediatrics 2001; 107: E75.

6. Instituto National de Estadística, Geografía e Informática. XII Censo General de Población y Vivienda 2000. Aguascalientes, México: INEGI; 2001.

7. Pennington C. The Tarahumara of Mexico. Salt Lake City, UT: University of Utah Press; 1963.

8. Pelto G. Ethnographic studies of the effects of food availability and infant feeding practices. Food Nutr Bull 1983; 6: 33-43.

9. Scrimshaw NS, Gleason GR, eds. Rapid assessment procedures. Qualitative methodologies for planning and evaluation of health related programs. Boston, MA: International Nutrition Foundation for Developing Countries; 1992.

10. Weller SC, Romney AK. Systematic data collection. Thousand Oaks, CA: Sage; 1988.

11. Bernard HR. Research methods in anthropology: qualitative and quantitative approaches. Newbury Park, CA: Sage; 1994.

12. Morgan DL. Focus groups as qualitative research. Qualitative research methods, vol. 16. Thousand Oaks, CA: Sage; 1996.

13. Kaptona-Apte J. Issues in food aid and nutrition. In: United Nations Administrative Committee on Coordination/Sub-Committee on Nutrition (UN ACC/SCN). Nutritional issues in food aid ACC/SCN Symposium report. Nutrition Policy Discussion Paper No. 12. Geneva: UN ACC/SCN; 1993. p. 5-20.

14. Bentley ME. The household management of childhood diarrhea in rural north India. Soc Sci Med 1988; 27: 7585.

15. Creed-Kanashiro H, Fukumoto M, Bentley ME, Jacoby E, Verzosa C, Brown $\mathrm{K}$. Use of recipe trials and anthropological techniques for the development of a home-prepared weaning food in the central highlands of Peru. J Nutr Educ 1991; 23: 30-5.

16. Martinez-Salgado H, Calva-Mercado JJ, Meneses-Diaz LM, Viais-Juarez H. The use of beverages and food at home during acute infantile diarrhea: an ethnographic study in a rural Mexican area. Bol Med Hosp Infant Mex 1991; 48: 235-42.

17. Jinadu MK, Odebiyi O, Fayewonyom BA. Feeding practices of mothers during childhood diarrhea in a rural area of Nigeria. Trop Med Int Health 1996; 1: 684 9.

18. Katona-Apte $\mathbf{J}$. The significance of intra-household food distribution patterns in food programmes. Food Nutr Bull 1983; 5: 35-41. 
19. Pelto G. Intra-household food distribution patterns. Malnutrition: determinants and consequences. Curr Top Nutr Dis 1984; 10: 285-93.

20. Reed BA, Habicht JP. Sales of food aid as sign of distress, not excess. Lancet 1998; 351: 128-30.

21. Walsh CM, Dannhauser A, Joubert G. The impact of a nutrition education programme on the anthropometric nutritional status of low-income children in South Africa. Public Health Nutr 2002; 5: 3-9.

22. Ghosh S, Kilaru A, Ganapathy S. Nutrition education and infant growth in rural Indian infants: narrowing the gender gap? J Indian Med Assoc 2002; 100: 483-90.

23. Mitzner K, Scrimshaw NS, Morgan R, eds. Improving the nutritional status of children during the weaning period. Boston, MA: Massachusetts Institute of Technology; 1984.

24. Jennings J, Gillespie S, Mason J, Lotfi M, Scialfa T, eds. Managing successful nutrition programs: community participation. Nutrition Policy Discussion Paper No. 8. Geneva: United Nations Administrative Committee on Coordination/Sub-Committee on Nutrition; 1991. p. 3344.

25. United Nations Administrative Committee on Coordination/Sub-Committee on Nutrition (UN ACC/SCN). How nutrition improves: state-of-the-art series. Nutrition Policy Discussion Paper No. 15. Geneva: UN ACC/ SCN; 1996.

\footnotetext{
Dr Joel Monárrez-Espino

Uppsala University

Department of Women's and Children's Health

University Hospital

SE-75I 85 Uppsala, Sweden

Tel: +46 18 6115937

Fax: +4618508013

E-mail: Joel.Monarrez@kbh.uu.se
} 